UDC: 620.93:633.18 (477)

\title{
RICE BY-PRODUCTS - RAW MATERIALS FOR ALTERNATIVE ENERGY PRODUCTION IN UKRAINE
}

\author{
H. MARUSHCHAK ${ }^{1}$, M. LISOVYI ${ }^{2}$, N. BIRINA ${ }^{2}$ \\ ${ }^{1}$ Rice Research Institute National Academy of Agrarian Sciences of Ukraine, \\ Antonivka, Skadovsk District, Kherson Region \\ ${ }^{2}$ National University of Life and Environment Sciences of Ukraine, Kyiv
}

Assessment of bioenergy potential of rice varieties showed that by-products (straw and husk) of Vikont and Premium demonstrate the highest values of energy output; these varieties were studied to establish how the agronomic factors affect the formation of rice productivity with the final products meant for food and straw and husk being a source of bioenergy plant material as a solid biofuel. In field experiments the biggest yields of rice were obtained under applied mineral fertilizers $N_{180} P_{60} K_{0}$ with seeding rate of 9 million of similar seeds per hectare for Vikont and Premium varieties at the levels of 9 and 8 t/ha, respectively. Thus, the optimal combination of rice farming techniques leads to high yields of the crop, and at the same time, to significant amounts of by-products suitable for further use.

The results of the study showed that rice straw should be used as a source of alternative energy, ricegrowing regions of Ukraine could get heat energy equivalent to the amount released during combustion of 62 million $\mathrm{m}^{3}$ of gas. The economic effect of the transition from gas heat generators to the biomass heat generators leads to annual cost cutout of USD 192.3 thousand, and the payback period is 1.14 year. An additional source of alternative energy is the rice husk; the payback of launching a rice husk briquetting line is 1.6 year.

Key words: rice straw, husk, bioenergy, solid biofuel, yield 
Introduction. Energy deficit is a daunting challenge recently faced by humanity which urges scientists to actively search for effective alternatives of conventional energy sources. One of the most promising ways of obtaining energy is its accumulating by biomass. The effectiveness of producing alternative biological fuels is determined by rational selection of plants types and how intensively the plants form biomass of the necessary chemical composition [1]. Considering the dependence on gas imports, which price has tripled over the past five years for Ukraine, it's necessary to search for alternative energy sources and implement strong energy policy and energy saving. A number of programs and regulations developed and adopted in this country aim to search for alternative energy sources and introducing energy intensive technologies under the Energy Strategy of Ukraine till 2030. Currently, the country imports $60 \%$ of energy, and by 2030 this dependence should be reduced to $11 \%$ [2].

Farm production in Ukraine has significant potential of biomass available for producing energy. Its main components are the energy crops and agricultural residues. Among the latter, the greatest energy potential is offered by the residues of sunflower production (stalks, husks), somewhat less - by residues of buckwheat and rice production.

Improving farm power sources cannot be achieved without raising the efficiency of use and involving in the energy balance of local fuels, biomass, plants residues and alternative energy sources. The main focus of energy saving in farm production is the development of resource saving technologies. Recently, the farm sector of Ukraine has been showing a growing interest in waste-free production based on the principle of complete utilization of raw materials, more specifically, residues.

Food industry technological processes commonly leave heavy tonnage wastes with their larger part derived from processing of grain being secondary raw materials that can be a source of a large number of products, and what is more, they would not require involving new sources of raw materials. However, the current extent of using secondary raw materials remains low in this country; out of the whole range of grain processing industry, the companies producing cereals use this type of resources in the 
least degree, although the renewable farm wastes should be approached as promising stock of materials useful for people.

An integral part of the rice grain is the husk which is separated from the grain during processing. In the weight part, the portion of husk makes $15-20 \%$ of the total mass of rice grain [4]. Since the destruction of rice husk is a very long process, the plowing it into the soil for its remediation does not solve the problem of recovery; the same situation is with using of this by-product for padding flooded areas. Thus, we observe the annual growth of a large amount of valuable energetic plant raw materials, which have not yet found an effective application [5].

Similar to other countries, Ukraine faces a pressing problem of recycling of crop residues after harvesting grain crops. The simplest method - burning straw - is the mostly wide spread. Obviously, the simplest methods do not always mean the most efficient ones; also, the burning of crop residues irreparably harms the biodiversity of ecosystems thus contributing to the ecological imbalance under global environmental changes [3].

The major part of the rice straw is burnt, although it is recommended to be used as feed, fertilizers, building materials. In other countries, the rice straw is quite popular for crafting a variety of woven products - baskets, hats, sandals, mats and even bags. For this purpose, the straw of rice glutinous breeds is preferred, since it is thinner and stronger than the straw of usual varieties.

Considering the quite long list of ways to use the by-product of rice cultivation, the problem of wastes recycling should not arise; however, due to a number of reasons stemmed from economic and social factors, most of them find no practical application. Most producers are not even aware of the possibility to use straw, husk and bran as raw materials for industry. But the fundamental reason is the lack of technology package that would consider the local conditions; at the same time, a fairly large volume of information on many manufacturing processes is easily accessible; also, development of technological parameters of production requires relatively small amount of data. 
Material and methods. To establish the influence of the main agronomic cultivation techniques of modern rice varieties in the South of Ukraine on the qualitative characteristics of grain and raw materials for biofuels, the field experiments were conducted in 2010-2013 in the fields of Rice Research Institute at Krasnoznam'yanska irrigation system area. The experiment crop management practices met the recommendations of Rice Research Institute, the land treatment and mechanization rate were typical for rice farms in the South of Ukraine except for the factors of interest. The soil at test plots was meadow-chestnut, moderately loamy, residual alkaline. The top soil contained humus $2.27 \%$, lightly hydrolyzed nitrogen by method of Tyurin \& Kononova $-4.8 \mathrm{mg} / 100 \mathrm{~g}$ soil, labile phosphorus - 3.9, potassium - $31 \mathrm{mg} / 100 \mathrm{~g}$ soil by method of Machygin, $\mathrm{pH}$ of aqueous recovery - 7,9. The rice seeds were planted by 'Klen 1,5C' seeder. The harvest was collected by direct combine harvesting by 'Yanmar' small-sized combine followed by adjusting the grain to the standard characteristics: $100 \%$ purity and $14 \%$ humidity. The results of the experiments were calculated by analysis of variance using the application software MSExsel and Statistica 5.0.

Results and discussion. Assessment of bioenergy potential of rice varieties (Tab. 1) showed that by-products (straw and husk) of Vikont and Premium demonstrate the highest values of energy output; these varieties were studied to establish how the agronomic factors affect the formation of rice productivity with the final products meant for food and straw and husk being a source of bioenergy plant material as a solid biofuel.

Favorable climate of Southern Ukraine and availability of rice irrigation systems provide the chances to obtain good yields of high quality rice grain, leaving, at the same time, the significant amounts of by-products in the form of straw, husk and bran which are sources of raw materials for solid biofuel.

In Ukraine, with 22-25 ha rice cultivation area, the gross harvests of paddy rice in 2012 amounted to 159.8 thousand tones, and in 2013 - 145.1 thousand tones. The gross collection of rice straw is about 160 thousand tones; should it be used as a 
source of alternative energy, the rice regions of Ukraine could get heat energy equivalent to the amount released during combustion of 62 million $\mathrm{m}^{3}$ of gas.

Table 1

Total yield of paddy and by-product of different rice varieties

\begin{tabular}{lccc}
\hline \multirow{2}{*}{ Variety } & Yield $\left(\mathrm{t} \mathrm{ha}^{-1}\right)$ & \multicolumn{2}{c}{ Amount $\left(\mathrm{t} \mathrm{ha}^{-1}\right)$} \\
\cline { 3 - 4 } & & husk & straw \\
\hline Pamyati Gichkina & 8.03 & 1.48 & 12.32 \\
\hline Jantarniy & 6.48 & 1.23 & 10.27 \\
\hline Agat & 7.00 & 1.08 & 10.36 \\
\hline Prestizh & 7.04 & 1.26 & 1.38 \\
\hline Serpnevy & 8.81 & 1.57 & 19.36 \\
\hline Premium & 8.82 & 1.65 & 17.29 \\
\hline Vikont & 9.11 & 1.62 & 15.36 \\
\hline Ontario & 9.63 & 1.60 & 15.60 \\
\hline Ukraine-96 & 7.82 & 1.46 & 0.83 \\
\hline LSD p $=0.05:$ & 0.54 & 0.19 & \\
\hline
\end{tabular}

On average, over the three years of the experiment, the yields ranged from 4.36-9.53 $\mathrm{t} \mathrm{ha}^{-1}$ (Tab. 2); it should be noted that Vikont variety formed larger harvests compared to Premium variety, an average of the experiment being 7.54 and $6.38 \mathrm{tha}$ ${ }^{1}$, respectively. According to our data, the crop yield of the researched rice varieties was in direct proportion to the use of mineral fertilizers and seeding rates.

Thus, the lowest value of this rate was observed at minimal values of the studied factors -6.17 and $4.36 \mathrm{t} \mathrm{ha}^{-1}$ respectively for Vikont and Premium varieties. The increase of the seeding rate of Vikont rice variety with $\mathrm{N}_{0} \mathrm{P}_{0} \mathrm{~K}_{0}$ led to decrease in grain yield, but the difference between options remained within the research. The biggest yields were obtained under applied $\mathrm{N}_{180} \mathrm{P}_{60} \mathrm{~K}_{0}$ with seeding rate of 9 million seeds $\mathrm{ha}^{-1}$ for Vikont and Premium varieties at the levels of 9 and $8 \mathrm{tha}^{-1}$, respectively. 
Table 2

Yield of rice depending on the variety, fertilization and crop seeding rates $\left(\mathrm{t} \mathrm{ha}^{-1}\right)$ in 2011-2013

\begin{tabular}{|c|c|c|c|c|c|c|}
\hline \multirow{2}{*}{$\begin{array}{l}\text { Variety } \\
\text { (factor } \\
\text { A) }\end{array}$} & \multirow{2}{*}{$\begin{array}{l}\text { Seeding rates, } \\
\text { million seeds ha } \\
\quad(\text { factor } \mathrm{C})\end{array}$} & \multicolumn{3}{|c|}{ Doze of fertilizers (factor B) } & \multirow{2}{*}{$\begin{array}{l}\text { Mean } \\
\text { (factor } \\
\text { A) }\end{array}$} & \multirow{2}{*}{$\begin{array}{c}\text { Mean } \\
\text { (factor } \\
\text { C) }\end{array}$} \\
\hline & & $\mathrm{N}_{0} \mathrm{P}_{0} \mathrm{~K}_{0}$ & $\mathrm{~N}_{90} \mathrm{P}_{30} \mathrm{~K}_{0}$ & $\mathrm{~N}_{180} \mathrm{P}_{60} \mathrm{~K}_{0}$ & & \\
\hline \multirow{3}{*}{ Vikont } & 5 & 6.17 & 6.95 & 7.60 & \multirow{3}{*}{7.54} & 6.58 \\
\hline & 7 & 6.90 & 7.58 & 8.62 & & 7.01 \\
\hline & 9 & 6.78 & 7.69 & 9.53 & & 7.28 \\
\hline \multirow{3}{*}{ Premium } & 5 & 4.36 & 6.87 & 7.54 & \multirow{3}{*}{6.38} & \\
\hline & 7 & 4.51 & 6.40 & 8.10 & & \\
\hline & 9 & 4.99 & 6.15 & 8.53 & & \\
\hline \multicolumn{2}{|c|}{ Mean (factor B) } & 5.62 & 6.94 & 8.32 & & \\
\hline \multicolumn{7}{|c|}{$\begin{array}{l}\text { LSD } \mathrm{p}=0.05 \text { for: } \mathrm{A}-0.39 ; \mathrm{B}-0.47 ; \mathrm{C}-0.47 ; \text { interaction } \mathrm{AB}-0.67 ; \mathrm{AC}-0.67 ; \mathrm{BC}- \\
0.82 ; \mathrm{ABC}-1.17\end{array}$} \\
\hline
\end{tabular}

It was found that the amount of rice by-products is proportional to the amount of the yield obtained. The average amount of straw in experiment made $7.13 \mathrm{t} \mathrm{ha}^{-1}$ for three years, with its highest value of $12.26 \mathrm{tha}^{-1}$ for Vikont variety, and $8.01 \mathrm{tha}^{-1}$ for Premium variety (Tab. 3).

Table 3

Amount of rice husk and straw obtained in the experiment variants $\left(\mathrm{tha}^{-1}\right)$ in 2011-2013

\begin{tabular}{|c|c|c|c|c|c|c|}
\hline \multirow{2}{*}{$\begin{array}{l}\text { Variety } \\
\text { (factor } \\
\text { A) }\end{array}$} & \multirow{2}{*}{$\begin{array}{l}\text { Seeding rates, } \\
\text { million seeds } \text { ha }^{-1} \\
\quad(\text { factor } \mathrm{C})\end{array}$} & \multicolumn{3}{|c|}{ Doze of fertilizers (factor B) } & \multirow{2}{*}{$\begin{array}{l}\text { Mean } \\
\text { (factor } \\
\text { A) }\end{array}$} & \multirow{2}{*}{$\begin{array}{l}\text { Mean } \\
\text { (factor } \\
\text { C) }\end{array}$} \\
\hline & & $\mathrm{N}_{0} \mathrm{P}_{0} \mathrm{~K}_{0}$ & $\mathrm{~N}_{90} \mathrm{P}_{30} \mathrm{~K}_{0}$ & $\mathrm{~N}_{180} \mathrm{P}_{60} \mathrm{~K}_{0}$ & & \\
\hline \multirow{6}{*}{ Vikont } & \multirow{2}{*}{5} & $1.32 *$ & 1.54 & 1.73 & \multirow{6}{*}{$\begin{array}{l}1.71 \\
8.19\end{array}$} & 1.42 \\
\hline & & $4.95 * *$ & 7.59 & 8.62 & & 6.37 \\
\hline & \multirow{2}{*}{7} & 1.59 & 1.92 & 1.94 & & 1.59 \\
\hline & & 6.95 & 7.48 & 10.34 & & 7.33 \\
\hline & \multirow{2}{*}{9} & 1.59 & 1.72 & 2.05 & & 1.63 \\
\hline & & 6.96 & 8.57 & 12.26 & & 7.67 \\
\hline \multirow{6}{*}{ Premium } & \multirow{2}{*}{5} & 0.92 & 1.42 & 1.61 & \multirow{6}{*}{$\begin{array}{l}1.38 \\
6.06\end{array}$} & \\
\hline & & 4.46 & 6.16 & 6.48 & & \\
\hline & \multirow[t]{2}{*}{7} & 1.01 & 1.37 & 1.69 & & \\
\hline & & 4.70 & 6.51 & 8.01 & & \\
\hline & \multirow{2}{*}{9} & 1.11 & 1.34 & 1.95 & & \\
\hline & & 5.42 & 5.48 & 7.35 & & \\
\hline \multirow{2}{*}{\multicolumn{2}{|c|}{ Mean (factor B) }} & 1.26 & 1.55 & 1.83 & & \\
\hline & & 5.57 & 6.96 & 8.84 & & \\
\hline \multicolumn{7}{|c|}{$\begin{array}{l}\text { LSD } \mathrm{p}=0.05 \text { for: } * \mathrm{~A}-0.20 ; \mathrm{B}-0.24 ; \mathrm{C}-0.24 ; \text { interaction } \mathrm{AB}-0.34 ; \mathrm{AC}-0.34 ; \mathrm{BC}- \\
0.42 ; \mathrm{ABC}-0.59 \\
* * \mathrm{~A}-0.31 ; \mathrm{B}-0.38 ; \mathrm{C}-0.38 ; \text { interaction } \mathrm{AB}-0.54 ; \mathrm{AC}-0.54 ; \mathrm{BC}-0.66 ; \mathrm{ABC}-0.93\end{array}$} \\
\hline
\end{tabular}


It is worth to mention that increased fertilization led to increased amount of straw for both studied varieties of rice: on average, 1.4 times for Vikont variety and 1.3 times for Premium variety. Increased seeding rates for Vikont variety under applied $\mathrm{N}_{90} \mathrm{P}_{30} \mathrm{~K}_{0}, \mathrm{~N}_{180} \mathrm{P}_{60} \mathrm{~K}_{0}$ led to increase of amount of straw on average by $14 \%$; however, this increase was insignificant for Premium variety, except for $\mathrm{N}_{90} \mathrm{P}_{30} \mathrm{~K}_{0}$ option with seeding rate of 9 million seeds ha $^{-1}$ which resulted in $27 \%$ decrease of the amount of straw.

Rice growing and next grain processing generate heavytonnage wastes in the form of husk. The analysis of rice grain determined the amount of husk and its sensitivity to various agronomic factors.

According to three-year data, the amount of husk was in range of 1.32-2.05 t $\mathrm{ha}^{-1}$ for Vikont variety and $0.92-1.95 \mathrm{t} \mathrm{ha}^{-1}$ for Premium variety, with the highest unit due to high doses of nitrogen fertilizers. The essential difference in amounts of husk between fertilization options is observed only at lower fertilization rates for Vikont variety; for Premium variety, the difference remains within research. This value was less influenced by seeding rates: for instance, the output of husk from both rice varieties was almost at the same level with the seeding rates of 7 and 9 million of similar grains per area unit, except for Vikont variety under applied $\mathrm{N}_{180} \mathrm{P}_{60} \mathrm{~K}_{0}$.

The results of the researches of 2011-2013 suggest that the optimal combination of rice farming techniques leads to high yields of the crop, and at the same time, to significant amounts of by-products suitable for further use.

Rice Research Institute has developed and introduced to the production the program of transition from the traditional energy sources (natural gas) for drying grain and seeds and heating office premises and technical facilities to non-traditional ones which use biomass originating from cultivating of crops. Under this program, the test farm built a grain drying complex operating on biomass; this facility is designed for drying the pretreated material: food or feed grain, cereals seeds, pulse and oil crops using the air which is heated in heat generator by combustion of biomass. 
The experience in application of straw crop driers in Ukraine showed that the economic benefits are achieved by using the own cheap fuel - straw. The straw can 6 times reduce the fuel costs necessary to dry 1 ton of grain. The market offers heat generators designed to produce heat energy in the form of air heated by burning the straw pressed in rectangular or round shape bales (rolls). The advantage of using heat generators of this type is that the air heated in them is isolated from the flue gases and contains no carcinogens. Besides, these heat generators can be mounted both in new dryers of various types and in reconstructed dryers of domestic and foreign origin.

The grain drying complex which operates on biomass and is designed for drying the pretreated material: food or feed grain, cereals seeds, pulse and oil crops using the air which is heated in heat generator by combusting biomass allows to create an economically and environmentally safe technology for drying grain. If constantly operating, the grain drying complex equipped with two heat generators has the output of 16 tons per hour lowering the moisture of rice grains by $4 \%$ in a single pass.

When using the straw as a source of energy, the fuel costs are reduced by 10.3 times compared to the natural gas necessary to dry 1 ton of grain. The transition from gas heat generators to the biomass heat generators leads to annual cost cutout of USD 192.3 thousand, and the payback period is 1.14 year.

An important element of the implementation of the energy-saving program is the use of rice husk. The administrative offices, schools, cultural centers, kindergartens and other buildings can be heated by boilers with power from $15 \mathrm{~kW}$ to $500 \mathrm{~kW}$. The equipment consists of a boiler and a combustion chamber with automatic fuel supply; the chamber is equipped with systems controlling water temperature, amount of fuel supplied, burning period, and amount of air supplied during combustion. Using this type of boiler saves up to $40 \%$ of energy compared with other fuels such as gas and coal, as well as allows to use the own raw materials as cheap energy resources.

To become suitable for fuel, the rice husk is to be briquetted. The screw press helps to obtain square briquettes without binding components. The principle of the 
press operation is based on continuous extrusion process; its output passes through the following stages: extrusion, forming, surface annealing which gives the briquette the dark brown color. Influenced by pressure and temperature, the natural compound - lignin - is plasticized and secreted to the briquette surface creating a protective shell. The press output is 4 tons of briquetted raw materials per hour, i.e. a 7-hourshift can produce 2 tons of high-quality environmentally friendly solid fuel. The using of fuel briquettes instead of the natural gas for heating premises leads to annual cost cutout of USD 237.9 thousand, and the payback period is 1.6 year.

\section{CONCLUSIONS}

The biggest yields of rice grains were obtained under applied mineral fertilizers $\mathrm{N}_{180} \mathrm{P}_{60} \mathrm{~K}_{0}$ with seeding rate of 9 million of similar seeds per hectare for Vikont and Premium varieties at the levels of 9 and $8 \mathrm{t} / \mathrm{ha}$, respectively. Thus, the optimal combination of rice agro-technology practices leads to high yields of the crop, and at the same time, to significant amounts of by-products suitable for further use.

Should the rice straw be used as a source of alternative energy, ricegrowing regions of Ukraine could get heat energy equivalent to the amount released during combustion of 62 million $\mathrm{m}^{3}$ of natural gas. The economic effect of the transition from gas heat generators to the biomass heat generators leads to annual cost cutout of USD 192.3 thousand, and the payback period is 1.14 year.

An additional source of alternative energy in rice farming is the rice husk. The payback of launching a rice husk briquetting line is 1.6 year.

\section{REFERENCES}

1. Bioenergy - a sustainable and reliable energy source, IEA Bioenergy / [Bauen A., Berndes G., Junginger M. et al.]. - 2009. - Mode of access: https://www.ieabioenergy.com/wp-content/uploads/2013/10/MAIN-REPORTBioenergy-a-sustainable-and-reliable-energy-source.-A-review-of-status-andprospects.pdf

2. Energy strategy of Ukraine till 2030. Available online at http://www.iea.org/publications/freepublications/publication/uk_summaryplus.pdf 
3. Ferrero A. The sustainable development of rice-based production systems in Europe / Ferrero A., Nguyen V.N. // Proceedings of the FAO Rice Conference "Rice is Life". - 2004. - Vol. 53. - P. 115-124.

4. Juliano B.O. Grain quality evaluation of world rices. IRRI / Juliano B.O., Villareal C.P. $\quad-\quad$ 1993. $\quad-\quad$ Mode of access: http://books.irri.org/9712200396_content.pdf

5. Biomass as feedstock for a bioenergy and bioproducts Industry / Perlack R., Wright L., Turhollow A. et al.]. - 2005. - Mode of access: //feedstockreview.oml.gov/pdf/billion_ton_vision.pdf.

\title{
ПОБІЧНА ПРОДУКЦІЯ РИСІВНИЦТВА - СИРОВИНА ДЛЯ АЛЬТЕРНАТИВНОГО ВИРОБНИЦТВА ЕНЕРГІЇ В УКРАЇНІ
}

\author{
Г.М. МАРУЩАК ${ }^{1}$, М.М. ЛІСОВИЙ ${ }^{2}$, Н.О. БІРІНА ${ }^{2}$ \\ ${ }^{1}$ Інститут рису НААН, с. Антонівка, Скадовський р-н, Херсонська обл. \\ ${ }^{2}$ Національний університет біоресурсів і природокористування України, \\ м. Київ
}

Оцінка біоенергетичного потенціалу сортів риса показала, що побічні продукти (солома і лушпиння) сортів «Віконт» $\mathrm{i}$ «Преміум» демонструють самі високі значення виходу енергії. Ці сорти були вивчені, щоб встановити, як агрономічні чинники впливають на формування продуктивності риса, а також кінцевих продуктів, призначених для харчових продуктів, соломи і лушпиння. У польових експериментах найбільші урожаї риса були отримані при внесенні мінеральних добрив $\mathrm{N}_{180} \mathrm{P}_{60} \mathrm{~K}_{0} 3$ нормою висіву 9 млн. аналогічного насіння на гектар для сортів «Віконт» і «Преміум» на рівнях 9 і 8 т/га відповідно. Таким чином, оптимальне співвідношення методів вирощування риса призводить до високої урожайності i, в той же час, до накопичення значної кількості побічних продуктів, придатних для подальшого використання. 
Результати дослідження показали, що рисова солома може бути використана в якості джерела альтернативної енергії, а рисові регіони України можуть отримувати теплову енергію, еквівалентну кількість, яку отримують 3 62 млн. м³ газу. Економічний ефект переходу від газових теплогенераторів до теплогенератору на біомасі призводить до щорічного скорочення витрат на 192,3 тис. дол. США, а термін окупності становить 1,14 року. Додатковим джерелом альтернативної енергії є лушпиння рису. Термін окупності запуску лінії брикетування рисового лушпиння - 1,6 року.

Ключові слова: рисова солома, лушпиння, біоенергетика, тверде біопаливо, урожайність.

ПОБОЧНЫЕ ПРОДУКТЫ РИСОВОДСТВА - СЫРЬЕ ДЛЯ АЛЬТЕРНАТИВНОГО ПРОИЗВОДСТВА ЭНЕРГИИ В УКРАИНЕ

\section{Г.М. МАРУЩАК ${ }^{1}$, Н.М. ЛИСОВОЙ${ }^{2}$, Н.О. БИРИНА ${ }^{2}$}

${ }^{1}$ Інститут риса НААН, с. Антоновка, Скадовский район, Херсонская область

${ }^{2}$ Национальный университет биоресурсов и природопользования, г. Киев

Оценка биоэнергетического потенциала сортов риса показала, что побочные продукты (солома и шелуха) сортов «Виконт» и «Премиум» демонстрируют самые высокие значения выхода энергии. Эти сорта были изучены, чтобы установить, как агрономические факторы влияют на формирование продуктивности риса, а конечные продукты, предназначенные для пищевых продуктов, соломы и шелухи, являются источником биоэнергетического растительного материала в виде твердого биотоплива. В полевых экспериментах наибольшие урожаи риса были получены при внесении минеральных удобрений $\mathrm{N}_{180} \mathrm{P}_{60} \mathrm{~K}_{0}$ с нормой высева 9 млн. аналогичных семян на гектар для сортов «Виконт» и «Премиум» на уровнях 9 и 8 т/га 
соответственно. Таким образом, оптимальное сочетание методов выращивания риса приводит к высокой урожайности и, в то же время, к значительному количеству побочных продуктов, пригодных для дальнейшего использования.

Результаты исследования показали, что рисовая солома может быть использована в качестве источника альтернативной энергии, а рисоводческие регионы Украины могут получать тепловую энергию, эквивалентную количеству, выделяемому при сжигании 62 млн. м газа. Экономический эффект перехода от газовых теплогенераторов к теплогенераторам на биомассе приводит к ежегодному сокращению затрат на 192,3 тыс. долл. США, а срок окупаемости составляет 1,14 года. Дополнительным источником альтернативной энергии является рисовая шелуха. Срок окупаемости запуска линии брикетирования рисовой шелухи - 1,6 года.

Ключевые слова: рисовая солома, шелуха, биоэнергетика, твердое биотопливо, урожайность. 